\title{
Community Participation for Access to Justice to Children: a Road Map for Future
}

\author{
Ujjwala Sakhalkar, Rashmi Dubey
}

\begin{abstract}
Right to access to justice signifies creating an environment where people are aware of their rights and an effective remedy is available to them if any of their rights are violated. Access to justice does not merely refer to the formal mechanisms but also involve informal mechanisms which are available. Children enjoy special status under the constitution and hence are given different treatment. This is the groups which keeps on demanding new rights but are unable to claim them on their own because of immaturity in terms of their age and mental growth.

For this reason right to access to justice becomes extremely important for the children. In absence of this their grievances will remain unheard and no effective remedy will be given to them. Children are responsibility of all and therefore it is all of us who should work towards protection of their rights and overall development.

The present paper is built -up on the conviction that community can participate in protecting best interest of the child and make justice accessible to them. It focuses on the concept of access to justice, the normative structure for it in India and suggests few ways in which the community can participate in making access to justice reality for them
\end{abstract}

Index Terms: Right to Access to Justice, Community Participation, Human Rights of Children

\section{INTRODUCTION}

Access to justice in its broader sense can be defined as ability of people to seek and obtain a remedy through formal or informal institution, in compliance with human rights standards. There is no access to justice where citizens fear the system and consider it as alien. There are countries where appropriate or adequate access to justice is unavailable to the citizens or even if it is available it is technically difficult for the common man to understand. The concept of right to access to justice has under gone a significant change. Earlier right of access to justice was limited to judicial protection essentially for the aggrieved individual, his right to approach the court to seek remedy. In essence it means having recourse to an affordable, quick, satisfactory settlement of disputes from a credible forum. The phrase access to justice serves to focus on two basic purpose of legal system:

a) The legal system must be equally accessible to all,

b) The legal system is individually and socially just.

In a state like India where we find a diverse culture, it becomes obligatory for the state to ensure administration of justice which is fair, just and reasonable, irrespective of economic or other disability.

Revised Manuscript Received on 14 August, 2019.

Ms. UjjwalaSakhalkar,

Ms. RashmiDubey,

\section{RIGHT TO ACCESS TO JUSTICE AND CONSTITUTION OF INDIA}

Peace and harmony is very essential for the growth and development of a country which can be assured by fair administration of justice. The preamble of India provides for securing all citizens equality of status and opportunity along with justice- social, economic and political. The fundamental right enshrined in the part III of the constitution of India acts as a means to achieve the objectives mentioned in the preamble. The first one is article 14 which provides that the state shall not deny to any person equality before law or equal protection of law with in the territory of India. Article 14 uses two expressions "equality before law" and "equal protection of law". Both these terms look similar but they denote completely different connotation of equality. Equality before law means everyone is to be treated equal before law irrespective of their status. Thus non discrimination becomes the essence of this equality. Equal protection of law means that everyone should be given equal protection of law, even for those who are at less advantageous position so that they could avail the benefit of law as their affluent counterparts.

Article 21 of the Constitution provides that no person shall be deprived of his life or personal liberty except according to procedure establish by law. In the year 1978 the Supreme Court in Menaka Gandhi v. Union of India held that under Article 21 life and liberty of a person can be taken away only by the procedure establish by law. The procedure which can take away life and liberty of a person should be just, fair and reasonable. Any procedure established by law which does not provide for free legal aid for poor and illiterate people to ensure fair representation before court cannot be treated as just, fair and reasonable. So the hon'ble Supreme Court widened the scope of Article 21 to include provisions of free legal aid in it. The Hon'ble Supreme Court reaffirmed its stand in 1979 in a case HussainaraKhatoon v. Home Secretary, Bihar and included right to free legal aid in Article 21. The right to free legal service is clearly an essential ingredient of 'just, fair and reasonable' procedure which can take away the life and liberty of a person accused of an offence. This is a constitutional right of every accused person who is unable to engage a lawyer and secure legal services on account of reasons such as poverty. The state is under a mandate to provide a lawyer to an accused person if the circumstances of the case and the need of justice so require. Provided the accused person does not object to the provision of such lawyer.

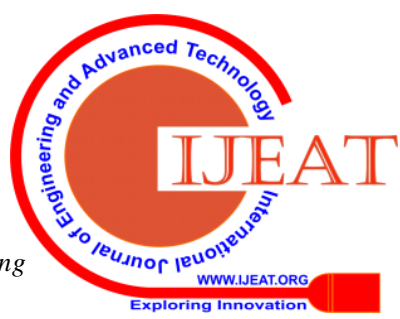


Right to Access to Justice can be enforced through Article 32 or Article 226 of the Constitution by approaching the apex court or the concerned High Court. Article 32 provides the right to move the Supreme Court for the enforcement of the fundamental rights provided under the Constitution of India.

The Supreme Court shall have power to issue directions or orders or writs in the nature of habeas corpus, mandamus, prohibition, quo-warranto and certiorari, whichever may be appropriate, for the enforcement of the fundamental rights. It is one of the highly cherished rights. It is very important and integral part of the basic structure of the constitution. It gives Supreme Court a status of the protector and guarantor of Fundamental Rights as it provides for the enforcement of fundamental rights in case of infringement. This right places State under an obligation to protect fundamental rights.

It is true that a declaration of fundamental right is meaningless unless there is effective machinery for the enforcement of the rights. It is the remedy which makes the right a reality. If there is no remedy there is no right. Article 226 also provides similar right as provided under Article 32 but it is not restricted to fundamental right. Its scope extends to fundamental as well as other rights.

\section{Guiding principles promoting access to justice:}

The relevance of Equal access to justice is not only supported by fundamental rights but also by directive Principles enshrined in part IV of the Constitution. They are not enforceable like fundamental rights but they are the guiding principles for governance of welfare State. Article 38, 39A, 41 \& 46 though not enforceable but has aptly guided the promotion of equal access to justice in India.

\section{(a) Welfare of People \& Access to Justice:}

The State is under an obligation to promote the welfare of the people by securing and protecting as effectively as it may, a social order in which justice- social, economic \& political shall inform all the institutions of the national life. Under Article 38, State is directed to strive to minimize the inequalities in income, to eliminate inequalities in status, facilities and opportunities, not only amongst individuals but also amongst groups of people residing in different areas or engaged in different vocations. Legal aid comes within the ambit of Article 38 as it diminishes the inequality due to economic factor and tries to bring equal opportunity of availing legal services irrespective of its affordability.

(b) Right to Free Legal Aid and Access to Justice:

Article 39-A provides that State shall secure the operation of the legal system which promotes justice, on a basis of equal opportunity, to provide free legal aid, by suitable legislation or schemes or in any other way, to ensure that opportunities for securing justice are not denied to any citizen by reason of economic or other disabilities. Article 39-A promotes justice on the basis of equal opportunities. It imposes an imperative duty upon the State to provide free legal aid to the poor. The Parliament of India in discharge of its obligation under Article this Article enacted The Legal Services Authorities Act, 1987 which provided for free legal aid. The 42nd amendment which inserted Article 39A also 10 Article 38, constitution of India Directive Principles Article 39 A Article 41 Article 46 Article 38 made some changes in schedule 7 of the Constitution of India. It removed the entry 3 that is administration of justice from State list and added it under concurrent list as entry 11-A. The object behind such change was to enable both union and State to make laws for legal aid and promotion of equal access of justice.

\section{(c) Right to public assistance and access to justice:}

The State is required under Article 41 of the constitution of India to provide for the public assistance in cases within the limits of its economic capacity and development. So State is under an obligation subject to its economic capacity to provide free legal aid to poor, illiterate or ignorant people.

\section{(d) Weaker section of society and Access to Justice:}

The State according to Article 46, is under an obligation to promote educational and economic interest of the weaker section of the people, and in particular, of the schedule castes and the schedule tribes to protect them from social injustice and all forms of exploitation. In this way the this Article has scope to bring within its ambit the obligation of State to make laws for providing free-legal aid to weaker sections of society including SC/ST so that they could avail equal access to justice which is essential for preventing social injustice and exploitation.

\section{(e) Provision for funds for promoting access to justice:}

Apart from preamble, Fundamental rights and directive principles, other Constitutional provisions also support the importance of legal aid and cast a duty on the State to provide legal aid to needy people. Article 282 provides that Union or a State may make grants for any public purpose .So under the preview of this Article the Union or the State can give grant for providing free legal aid, spreading legal awareness etc. which is a public purpose.

\section{(f) Residuary power to promote access to justice:}

The Article 142 (1) has been providing assistance in promoting access to justice in India. It provides that in the exercise of its jurisdiction the Supreme Court may pass such decree or make such order as is necessary for doing complete justice in a matter pending before it.

It helped the Supreme Court in providing equal access to justice till there was no separate enactment for free legal service by interpreting the provisions of preamble, fundamental rights and directive principles in such a way as to bring free legal aid within the scope of fundamental right. Now when we have separate enactment for free legal aid and advice is helping Supreme Court to interpret the provisions of this Act in such a way that its object of providing equal access could be achieved in true sense.

It is now evident from above explanation that equal access to justice has very strong Constitutional backing from preamble, fundamental rights, directive principles and many other Articles of Constitution of India. Indian Judiciary and Parliament of India has also played pro-active role in effective implementation of these constitutional provisions. Various landmark judgments of Hon'ble Supreme Court and 
High Court have interpreted constitutional provisions in such a way so as to bring access to justice within its ambit. Enactment of Legal Services Authorities Act, 1987 has actually contributed in bringing right to access to justice closer to reality.

\section{WHY COMMUNITY PARTICIPATION IS IMPORTANT\& RESULTS}

Responsibility of the children is just not of the state but the entire society. A child is significantly different from an adult to have specialized treatment. He is not equipped with to deal with the vagaries of life despite the fact that many of them are running their life in their own manner without any interference from adults. An old proverb says, " It takes a village to raise a child and there are no such thing as other people's children". Therefore children become responsibility of all of us. Community participation is essential to ensure that children do not lose their childhood or are not deprived of basic needs in their reformative years. Community participation will bridge the gap between the children and them. In the formative stage they become vagrant and are exposed to different vices. They develop apathy towards the society and do not want the society to interfere in their life. The community participation will built up the trust in them again. The social integration becomes smooth and easy. The reformation and rehabilitation becomes an attainable goal. When the children come in conflict with law it is the also the responsibility of the community to ensure that justice is done to them. They are not left without being heard by an impartial independent body. Community participation in the entire justice process

\section{HOW DOES COMMUNITY PARTICIPATE?}

Community can participate in numerous ways to bring justice to the children. It is very for the community to ensure that the children voice does not remain unheard or their grievances go unnoticed. Following are the ways in which society can contribute:

\section{a) Legal empowerment}

The children can be made aware of their rights and entitlements. NGO'S, legal aid centers, child helpline can play a significant role in this. Many a times it happens that the children are not aware of their rights. Different capacity and potential building programmes can be held. Legal empowerment means not only the knowledge of legal rights but also having capacity to claim these rights.

\section{b) Counseling and helpline center}

Counseling plays an important role in the entire justice procedure. Children suffer from peer pressure, apathy for the entire justice system, revolting and hatred towards life and community. They remain in their own shell and develop a psychology where they become introvert or outspoken. At every stage for dispensing justice counseling is to be done. Where the judges feel they must take help of the counselor. Helpline centers are of great help because children do not have to disclose their identity and can disclose all their fears and anxiety without coming face to face. becomes essential.

\section{c) Representing children in the justice process}

Social workers, child psychologist, lawyers must represent the children and speak on their behalf whenever required. Right to representation is the important aspect of justice delivery system. Children whenever are unable to express their opinion because of immature understanding and age than it is important that the child must be represented.

\section{d) Community based programs}

It is essential that children should be involved in best planned and executed community based programs These plans must be well designed by the authorities which will in turn help children in their development and build thus help in the reformation and rehabilitation. These community based programme may range from training programs, festival celebrations, workshops relating to dance drama and coaching etc. active participation from both sides will help the community and the children.

\section{e) Helping as an interpreter}

Sometimes in the entire process children face the problem of understanding the language of the authorities and are not able to express themselves. In such cases interpreting correctly for them is very essential. Community members can participate as interpreting what do the authorities say correctly and also encourage the child to communicate in the language he is comfortable with.

f) Informing them about the various Government schemes, policy and programmes

Knowing about the Government scheme and policies is essential for children. The community in collaboration with the authorities can hold workshop and programs informing them about the Government schemes and programmes.

\section{CONCLUSION}

Community plays an important role in making access to justice a reality for children. We have to seriously observe the changing trends of behavior among children and guide them accordingly. They should get full opportunity to enjoy their childhood, build their career and ultimately turn out to be a good human being. A child with negative personality should be transformed into a person having positive personality. Whenever they deviate and come in conflict with law community can help them to access justice. They are not to be looked as criminals beyond reformation and rehabilitation. Stigmatizing them as offenders will have negative impact on their formative stage. Giving them justice and fully recognizing their human rights and an approach for reformation and rehabilitation will make the entire justice system child friendly.

\section{REFERENCES}

1. Kumari Ved,The Juvenile Justice System in India : from welfare to rights, oxford university press, New Delhi, 
2004.

2. Durga Das Basu, Introduction to the Constitution of India, 1960

3. Legal Services Authorities Act 1987

4. Srivastava, Astha. "Patent And Competition Interface: Issues And Challenges In India." Int. j. of Social Science and Economic Research, vol. 4, no. 2, Feb. 2019, pp. 1521-1527, ijsser.org/more2019.php?id=111.

5. Sarda, M., Deshpande, B., Shringarpure, S.: "Smart city - Use of technology and the needed labor reforms", International Journal of Innovative Technology and Exploring Engineering 2018.

6. Sarda, M., Deshpande, B., Deo, S., Karanjkar, R.: “A comparative study on Maslow's theory and Indian Ashrama system", International Journal of Innovative Technology and Exploring Engineering, 2018.

7. Sarda, M., Deshpande, B., Dharm, J., Dhere, V.: "Different aspects of environmental laws", International Journal of Recent Technology and Engineering, 2019.

8. Deshpande, B., Girme, A. : "Research methods made simple", International Journal of Innovative Technology and Exploring Engineering, 2019.

9. Girme, A., Deshpande, B.: "The life line of human beings-"Right to potable water", International Journal of Recent Technology and Engineering, 2019.

10. Sinha, S., Deshpande, B., Deo, S., Vedpathak, S.: "Potential appeal mechanism by consent: Arbitration", International Journal of Recent Technology and Engineering, 2019.

11. Srivastava, A., Sinha, S.: "Cyber Delinquency: Issues and Challenges under Indian Legal System", International Journal of Engineering and Advanced Technology (IJEAT) 2019

12. Anuradha G., Revolutionary Yogic Agriculture, International Journal of Recent Technology and Engineering (IJRTE) ISSN: 2277-3878, Volume-8 Issue3, September 2019

13. Deo, S., Deo, S.: "Cybersquatting: Threat to domain name", International Journal of Innovative Technology and Exploring Engineering, 2019.

14. Deo, S., Deo, S.: "Domain name and its protection in India", International Journal of Recent Technology and Engineering, 2019.

15. Dubey, R., Sakhalkar, U.: "A critical analysis of rising intolerance and growing polarisation: Lynching", Journal of International Pharmaceutical Research, 2019.

16. Ujjwala Sakhalkar, Community Participation for access to Justice to children: A road map for future, International Journal of Recent Technology and Engineering,2019.

17. Salil Shringarpure, Internet Trolling: Analyzing the legal myths and facts, International Journal of Engineering and Advanced Technology, 2019.

18. Shaikh, A., Khandare, J.: "International parental child abduction in United States of America and India", International Journal of Engineering and Advanced Technology, 2019.

19. Khandare, J., Shaikh, A.: "When life becomes death: A stifling story of air pollution", Journal of International Pharmaceutical Research, 2019

20. Pathak, A., Mishra, A.: "Human trafficking in India", Journal of International Pharmaceutical Research, 2019

21. Bendale, U., Dhere, V.: "Right of aged persons to live with dignity: A socio-legal perspective", International Journal of Innovative Technology and Exploring Engineering, 2019

22. Dhere, V., Bendale, U.: "Impact of smart city on social relations", International Journal of Innovative Technology and Exploring Engineering, 2019.
23. SukrutDeo and Dr. SapnaDeo, "Cybersquatting: Threat to Domain Name", International Journal of Innovative Technology and Exploring Engineering, 2019

24. Srivastava, A., Sinha, S.: "Anti dumping policy and its effect on indian pharmaceutical sector ",International Journal of Engineering and Advanced Technology, 2019. 